\title{
Genosensor Study for Fetal Cell-Free DNA Detection
}

\author{
Umut Kökbaş $^{1 *}$, Abdullah Tuli² and Levent Kayrin ${ }^{1}$ \\ ${ }^{1}$ Medical Biochemistry, Department of Medical Faculty, University of Kyrenia, Cyprus \\ ${ }^{2}$ Medical Biochemistry Department of Medical Faculty, Cukurova University, Adana, Turkey \\ *Corresponding author: Umut KÖKBAŞ, Medical Biochemistry, Department of Medical Faculty, University of Kyrenia, Cyprus \\ To Cite This Article: Umut Kökbaș, Genosensor Study for Fetal Cell-Free DNA Detection. 2020 - 8(1). AJBSR.MS.ID.001228. \\ DOI: 10.34297 /AJBSR.2020.08.001228.
}

Received: 眥 March 02, 2020; Published: 盋 March 10, 2020

\begin{abstract}
$\beta$-Thalassemia is one of the most monogenic autosomal recessive disorder characterized by defective production of the hemoglobins $\beta$-chain. Definition of the $\beta$-globin genotype is necessary for genetic counselling in the carriers, and for predicting prognosis and management options in the patients with thalassemia. Genetic analysis of $\beta$-thalassemias routinely relies on polymerase chain reaction (PCR) and gel electrophoresis. The aim of this study is to develop a new procedure, a nanopolymer-based Lab-on-a-chip based biosensor for the real-time multiplex analysis of $\beta$ thalassemia mutations from Cell-Free DNA. In this study, biospecific interaction analysis (BIA) employing quartz-cristal microbalance (QCM) and biosensor technologies was applied to the analysis of multiple mutations of the human $\beta$-globin gene. To this aim, large target polymerase chain reaction products were immobilized on genosensor electrode and then probes detecting IVSI-110 $\beta$-thalassemia mutations were sequentially injected.
\end{abstract}

The results obtained allow to conclude that discrimination between normal subjects, heterozygous, and homozygous patients is readily achieved for all the five mutations by PCR amplification of genomic DNA containing all the regions corresponding to the same mutations, immobilization of the same PCR products, and hybridization. The developed biosensor serves as a specific result for all the five mutations. It could accurately discriminate the mutations. Because of low costs, fast results, specificity and high detection/information effectiveness as compared with conventional prenatal diagnosis methods.

Keywords: Cell-Free DNA; Genosensor; QCM

Abbreviations: BIA: Biospecific interaction analysis; DNA: Deoxyribonucleic ncid; PCR: Polymerase chain reaction; QCM: Quartz-cristal microbalance

\section{Introduction}

$\beta$-thalassemia is the most common hemoglobin genetic disorders and it is caused by the absent or reduced production of the hemoglobins $\beta$ globin chains [1,2]. $\beta$-thalassemia is prevalent in tropical and subtropical world regions where malaria was and still is epidemic, but as a consequence of the recent massive population migrations, $\beta$-thalassemia has become a relatively common clinical problem $[3,4]$. Therefore rapid genetic disorders identification systems like genosensor technologies gain importance for this health problem $[5,6]$. The DNA hybridization events has become the main principle in the construction of genosensor devices which consisting of single-stranded DNA (ssDNA) probes layer immobilized on a working electrode surface in order to recognize its complementary DNA target to form a DNA double helix formation.

This hybridization event is converted into a quantified signal by the transducer in the form of piezoelectric resonance and electrochemical for detection [7]. The electrochemical transducer has gained an interest for DNA hybridization detection because of its simplicity and direct convert to the hybridization events into the electrical signal $[8,9]$. The major advantages of electrochemical genosensor compared to other DNA sensor are it is amenable to miniaturization, compatible with microfabrication technique, required simple instrumentation, provide a remarkable sensitivity and selectivity, poses rapid response, easy to operate and has high portability, minimum power requirements and low-cost production $[6,10]$.

\section{Materials and Methods}

\section{Chemicals}

All chemicals used in genosensor were purchased from Sigma Chemical Co., USA. All solutions were prepared freshly just before experiment. 


\section{Apparatus}

Palm Sens potentiostat, and corundum ceramic based screen printed gold quartz cyristal electrode combined with the reference $\mathrm{Ag} / \mathrm{AgCl}$ electrode, and the auxiliary AuPd (98/2\%) electrode were used to perform the electrochmeical measurements. In the experiments, automatic pipets, a magnetic stirrer, and a thermostat were used. Ultra-pure water in the preparation of solutions was obtained water purification system.

\section{Preparation of the Genosensor}

Prior to coating with nanopolymer, the surface of au quartz cyristal electrode was polished with alumina slurries on microfiber cloth to obtain a mirror surface. The polished electrode was rinsed with double distilled water. In order to remove undisered absorbable particules, the electrode was sonicated first in pure ethanol and later in double distilled water for 10 minutes. In the next step, the electrochemical cleaning of electrode was accomplished by five successive cyclic voltammetric sweeps between -1.0 and +1.0 $\mathrm{V}$ in $0.1 \mathrm{M}$ HNO3 solution [11]. The bioactive layer was prepared by immobilizing DNA probes on the gold electrode with self assembled mono layer of Poly-Hema-Mac on the gold surface. All the measurements were executed in a thermostatic reaction cells $[12,13]$, contained varying amounts of DNA samples concentration on the bioactive surface.

\section{Principle of measurement}

The principle is based on the specific DNA hybridisation between DNA probes and ssDNA samples. Finally, the resonance difference during these reactions was measured by quartz cyristal.

\section{Results and discussion}

\section{Electrochemical characterisation of the genosensors plasmon resonance}

Genosensors cyclyc voltammogram obtained between -0.3 and 0.8 volt, this range used working range of genosensor (Figure 1). When using different concentrations normal, $\beta$ thalassemia heterozygote and $\beta$ thalassemia homozigote of DNA samples on the genosensors working electrode surface the resonance classified by hybrisidation affinity (Figure 2)

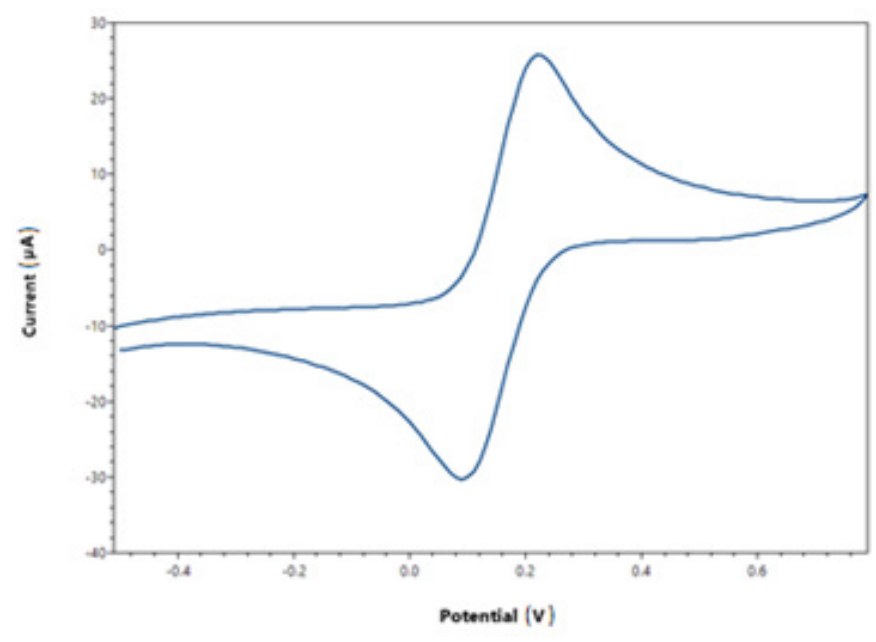

Figure 1: Cyclyc voltammogram of the genosensor.

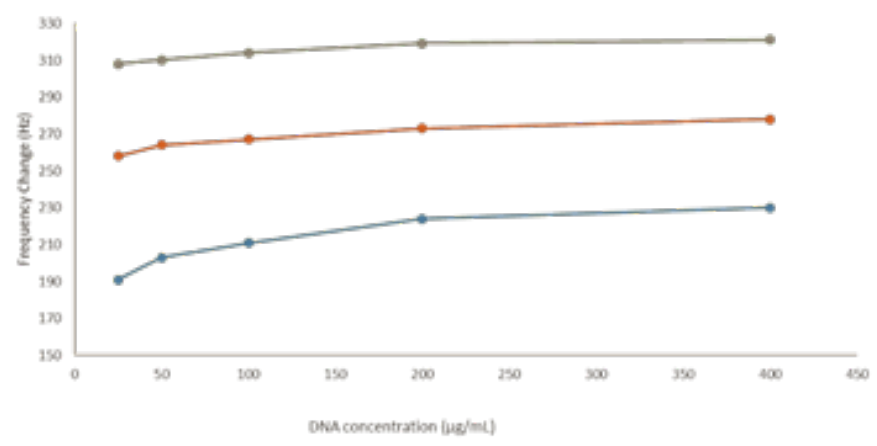

Figure 2: The plasmon resonance of normal, heterozygote and homozigote samples frequance. (Grey: heterozygote, Red: normal, Blue: homozygote). 


\section{Effect of $\mathrm{pH}$ on the biosensor response}

Biosensors based on an hybrizidation depends on a suitable buffer system and $\mathrm{pH}$ medium for obtaining the best responses [14]. To detect the effect of the $\mathrm{pH}$ value on the biosensor response, different buffer systems were investigated. For this aim, acetate (50 $\mathrm{mM}, \mathrm{pH}$ 4.0-5.0-6.0), phosphate ( $50 \mathrm{mM}, \mathrm{pH} 7.0$ ), and Glycine/ $\mathrm{NaOH}$ ( $50 \mathrm{mM}, 8.0$ ) buffers were used in the experiments. The optimum $\mathrm{pH}$ value was 7.5. Below and above pH 7.5 causes a decreases in the biosensor response (Figure 3).

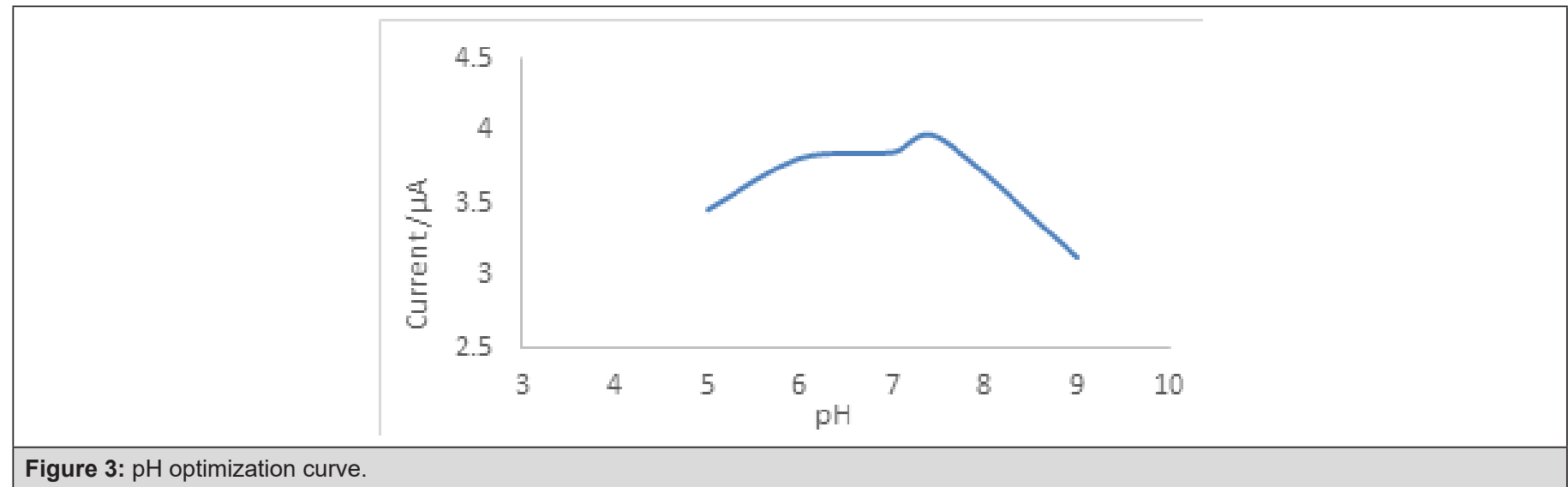

\section{Measurement of different concentrations of DNA sample}

25- $100 \mu \mathrm{g} / \mathrm{ml}$ of DNA samples concentration were prepared and measurements were taken under optimized conditions. When the DNA concentration increases, the response current rises at the mutation levels interval (Figure 4).

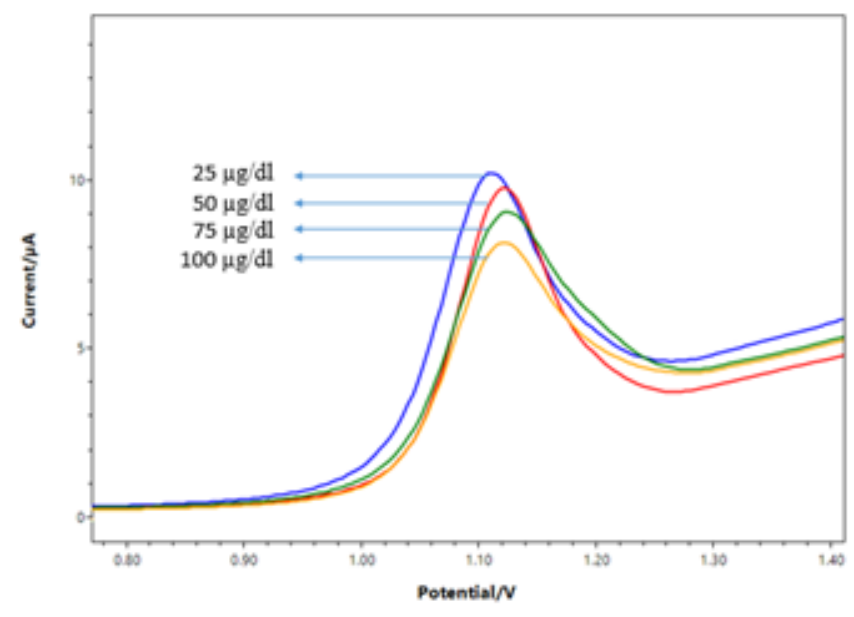

Figure 4: Measurement of different DNA amount on the genosensors working electrode surface.

\section{Conclusion}

As a result of this work, determination of $\beta$ thalassemia DNA samples by using genosensor system is a new approach $[15,16]$. Determination of point mutations with this method is also possible at low concentrations. According to literature the genosensor studies have known to be very sensitive, specific, simple and less time-consuming methods. Consequently, we can be suggested that development of the method would be an original and useful procedure for DNA samples determination. Therefore next step towards making the sensor for in vivo studies and more portable involves further miniaturization allowing in situ monitoring of signals.

\section{Acknowledgements}

This study was supported by Grant from the Cukurova University Scientific Research Projects Coordination Unit (Project Number: TDK-2017-8841).

\section{Conflict of Interest}

There are no conflicts of interest influencing the work reported in this paper.

\section{References}

1. Chen X (2019) Severe hemolytic anemia due to combined $\beta$ thalassemia and de novo Hemoglobin Sabine. Ann Hematol 98(3): 783-785. 
2. Ghadami E, Tamaddoni A, Sedaghat S, Tabaripour R, Pourreza Baboli H, et al. (2019) First Report of Association Between Rare $\beta$-Thalassemia Mutation (HBA1: c.298A>T) and Hb Fontainebleau (HBA2: c.64G>C). Indian J Clin Biochem 34(1): 115-117.

3. Wykretowicz J, Song Y, Mc Knight B, Choi SW, Magenau J, et al. (2019) A diagnosis of discernment: Identifying a novel ATRX mutation in myelodysplastic syndrome with acquired $\beta$-thalassemia. Cancer Genet 231-232: 36-40.

4. Xie YP, Cao YP, Zhu XJ, Liu HJ, Liu J, et al. (2019) [Values of Hematological Indicators in the Screening of -Thalassemia in Fujian Area of China] Zhongguo Shi Yan Xue Ye Xue Za Zhi 27(1): 165-169.

5. Pornprasert S, Anurak R, Ruengdit C, Pienthai N, Tookjai M, et al. (2019) Validation of Microarray for the Simultaneous Detection of Common and beta-Thalassemia Gene Mutations. Lab Med 50(3): 306-312.

6. Yamada N, Lai WKM, Farrell N, Pugh BF, Mahony S, et al. (2019) Characterizing protein-DNA binding event subtypes in ChIP-exo data. Bioinformatics 35(6): 903-913.

7. de Freitas Martins E, Troiano Feliciano G, Hendrik Scheicher R, Reily Rocha A (2019) Simulating DNA Chip Design Using All-Electronic Graphene-Based Substrates. Molecules 24(5).

8. Wang N, Lu Y, Chen Z, Fan R (2019) Multiplexed PCR-Free Detection of MicroRNAs in Single Cancer Cells Using a DNA-Barcoded Microtrough Array Chip. Micromachines (Basel) 10(4).

9. Wunsch BH, Wunsch Sung-Cheol Kim, Stacey M Gifford, Yann Astier, Chao Wang, et al. (2019) Gel-on-a-chip: continuous, velocity-dependent DNA separation using nanoscale lateral displacement. Lab Chip, Pubfacts Scientific publication Data.
10. Skutkova H, Martin Vitek, Matej Bezdicek, Eva Brhelova, Martina Lengerova, et al. (2019) Advanced DNA fingerprint genotyping based on a model developed from real chip electrophoresis data. Journal of Advanced Research 18: p. 9-18.

11. Yorganci E, E Akyilmaz (2011) Alkaline phosphatase based amperometric biosensor immobilized by cysteamine-glutaraldehyde modified self-assembled monolayer. Artif Cells Blood Substit Immobil Biotechnol 39(5): 317-323.

12. Gorenek G, E Akyilmaz, E Dinckaya (2004) Immobilization of catalase by entrapping in alginate beads and catalase biosensor preparation for the determination of hydrogen peroxide decomposition. Artif Cells Blood Substit Immobil Biotechnol 32(3): 453-61.

13. Ozturk G, Akyilmaz E, Dinçkaya E (2004) A novel amperometric biosensor based on artichoke (Cynara scolymus L.) tissue homogenate immobilized in gelatin for hydrogen peroxide detection. Artif Cells Blood Substit Immobil Biotechnol 32(4): 637-645.

14. Bruchmann J, Sachsenheimer K, Rapp BE, Schwartz T (2015) Multichannel microfluidic biosensor platform applied for online monitoring and screening of biofilm formation and activity. PLoS One 2015. 10(2): e0117300.

15. Aguayo D, Pacheco N, Morales EH, Collao B, Luraschi R, et al. (2015) Hydrogen peroxide and hypochlorous acid influx through the major $\mathrm{S}$. Typhimurium porin OmpD is affected by substitution of key residues of the channel. Arch Biochem Biophys 568: p. 38-45.

16. Lima DA, Aguiar FH, Pini NI, Soares LE, Martin AA, et al. (2015) In vitro effects of hydrogen peroxide combined with different activators for the in-office bleaching technique on enamel. Acta Odontol Scand 73(7): 516521. 